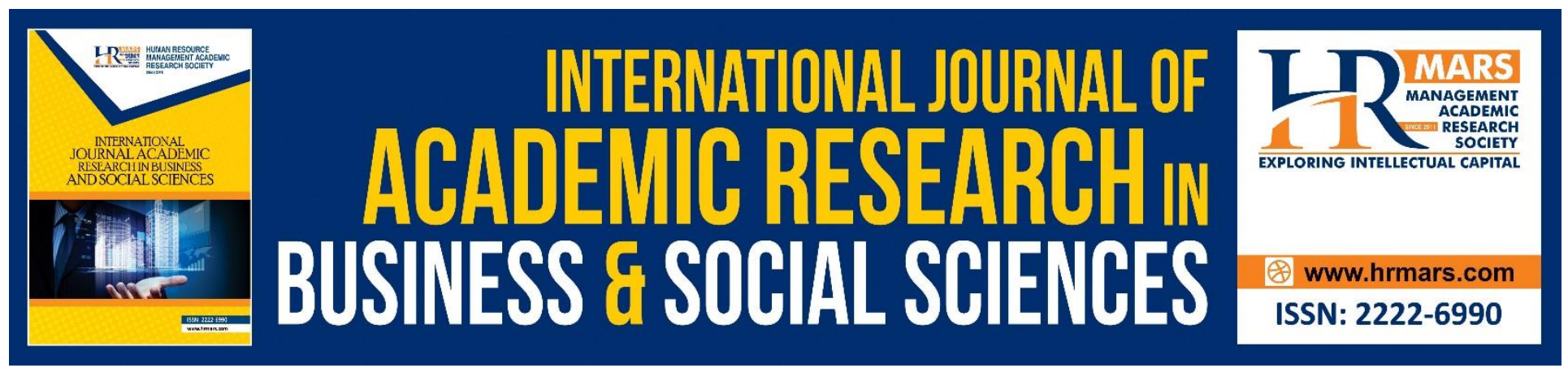

\title{
Seeking of Agriculture Information through Mobile Phone among Paddy Farmers in Selangor
}

Nor Sabila Ramli, Md Salleh Hassan, Norsida Man, Bahaman Abu Samah, Siti Zobedah Omar, Nur Atikah A Rahman, Sarina Yusuf and Muhamad Shamsul Ibrahim

To Link this Article: http://dx.doi.org/10.6007/IJARBSS/v9-i6/5969 DOI: $10.6007 /$ IJARBSS/v9-i6/5969

Received: 12 April 2019, Revised: 19 May 2019, Accepted: 09 June 2019

Published Online: 30 June 2019

In-Text Citation: (Ramli et al., 2019)

To Cite this Article: Ramli, N. S., Hassan, M. S., Man, N., Samah, B. A., Omar, S. Z., Rahman, N. A. A., ... Ibrahim, M. S. (2019). Seeking of Agriculture Information through Mobile Phone among Paddy Farmers in Selangor. International Journal of Academic Research in Business and Social Sciences, 9(6), 527-538.

Copyright: (C) 2019 The Author(s)

Published by Human Resource Management Academic Research Society (www.hrmars.com)

This article is published under the Creative Commons Attribution (CC BY 4.0) license. Anyone may reproduce, distribute, translate and create derivative works of this article (for both commercial and non-commercial purposes), subject to full attribution to the original publication and authors. The full terms of this license may be seen at: http://creativecommons.org/licences/by/4.0/legalcode

Vol. 9, No. 6, 2019, Pg. 527 - 538

Full Terms \& Conditions of access and use can be found at http://hrmars.com/index.php/pages/detail/publication-ethics 


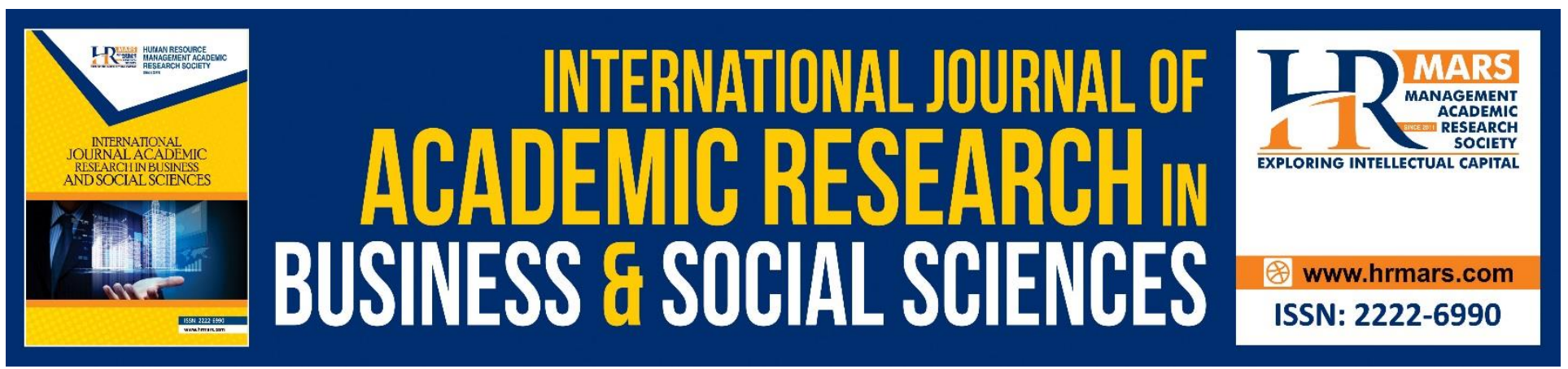

\title{
Seeking of Agriculture Information through Mobile Phone among Paddy Farmers in Selangor
}

\author{
Nor Sabila Ramli ${ }^{1}$, Md Salleh Hassan², Norsida Man³, Bahaman Abu \\ Samah $^{4}$, Siti Zobedah Omar ${ }^{1}$, Nur Atikah A Rahman ${ }^{5}$, Sarina Yusuf ${ }^{1}$ \\ and Muhamad Shamsul Ibrahim ${ }^{6}$ \\ ${ }^{1}$ Institute for Social Science Studies, Universiti Putra Malaysia, ${ }^{2}$ Faculty of Modern Language and \\ Communication, Universiti Putra Malaysia, ${ }^{3}$ Faculty of Agriculture, Universiti Putra Malaysia, \\ ${ }^{4}$ Faculty of Educational Studies, Universiti Putra Malaysia. ${ }^{5}$ School of Communication, Universiti \\ Sains Malaysia, ${ }^{6}$ Kolej University Poly-Tech MARA
}

\begin{abstract}
Introduction: Mobile phone is one of the communication tools that have always mattered in many fields included agriculture. The development of the agriculture sector in the rural area is significant to diminish poverty among farmers. Agricultural activities are known to provide opportunities for employment and generating income in the rural area. Poverty can be reduced through adequate investment and improvement in the agriculture sector. Enhancing the use of mobile phone will empower farmers with relevant agriculture information. Thus, agriculture production and profits as well as farmers' food security and livelihood will increase. Methodology: This study uses a quantitative approach, where an adopted and adapted questionnaire was employed to obtain the data needed. Through purposive sampling, 400 respondents were surveyed. The respondents selected were those who are involved in paddy farming in Selangor. Results: The finding of the study reveals that paddy farmers in Selangor are comfortable using mobile phones in seeking agricultural information. The result for communication apps indicates that WhatsApp is the best choice to get information using a mobile phone as 279 respondents responded they were comfortable using WhatsApp to get and share information through a mobile phone. Whereas, the highest agriculture information the farmers sought are information on pest control, farm safety information, and information on pesticide/weed. Conclusion/Recommendation: Due to the well-received mobile phones usage among farmers, it is recommended that organizations such as the Department of Agriculture and Barat Laut Selangor Integrated Agriculture Development Area (IADA) to improve strategies in distributing information on paddy farming using mobile phones.
\end{abstract}

Keywords: Information and Communication Technology, Mobile Phone, Poverty, Agricultural Sector 
INTERNATIONAL JOURNAL OF ACADEMIC RESEARCH IN BUSINESS AND SOCIAL SCIENCES

Vol. 9, No. 6, June, 2019, E-ISSN: 2222-6990 @ 2019 HRMARS

\section{Introduction}

Mobile phone has become an important need for everyone regardless of whether they from the urban or rural areas. The importance of mobile phones is undeniable. For farmers, efficiency in using mobile phones has significantly influenced the way they work and improve their living standards. A mobile phone helps to disseminate information with no time limit. According to Community Development (HRCA, 2001), the efficient use of mobile phones contributes to a positive impact on poor farmers, surrounding communities, and strengthens their position in the market chain. Efficient use of the mobile phones also encourages active participation to enhance the farmers' social and economic development. Yet, the rural community, especially the farmers, are challenged with many obstacles to using a mobile phone. Hosseini et al. (2009) indicated financial, organizational, technical, social, and illiteracy are the some of challenges.

\section{Mobile phone usage among farmers in Malaysia}

A report by Malaysian Communication and Multimedia Commission (2018) proved that our citizens prefer to use a smartphone the most to access the Internet compared to other devices (Figure 1.0). The increasing percentage of smartphones usage every year indicates that smartphones are one of the necessary tools to access the Internet. Smartphones are the most preferred device opted by Malaysians (93.1\%) to be connected to the Internet in 2018 compared to other devices. This is followed by using laptop/netbook (44.2\%), PC/ desktop (28.1\%), and tablet (20.4\%).

Figure 1.0: Device to access the Internet

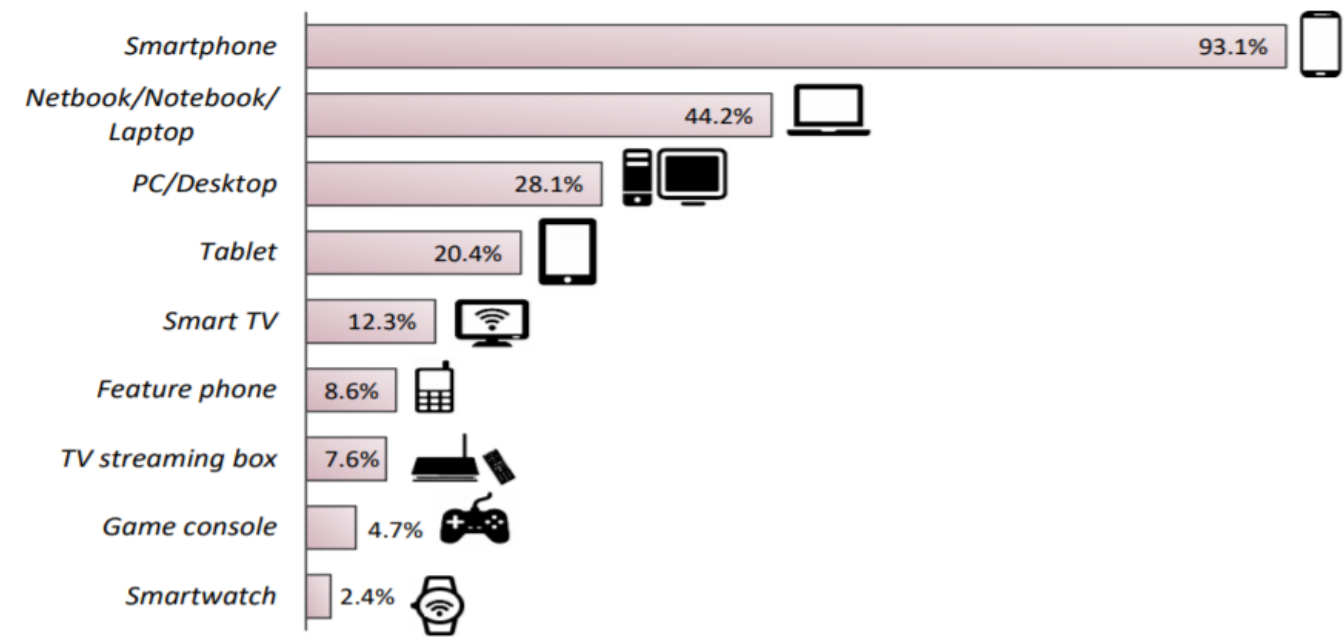

Source: Malaysian Communication and Multimedia Commission (MCMC), 2018

\section{Agriculture Information Distribution Through Mobile Phones in Malaysia}

Information is crucial in increasing agricultural production and improving marketing and it is one of the distribution strategies (Oladele, 2006). The significance to expanding agricultural production eventually lies with the country's capacity to disseminate important information to the farming community to facilitate effective adoption of new production techniques, use of farming information 
sources, decision-making on markets, costs, and techniques of conserving water, soil, and vegetable resources (Kiplagat, 1998).

Besides, mobile phones can distribute information through calls, text messages, WhatsApp, EMobile and search engines. Another benefit of mobile phones is that farmers can search for information at any time within twenty-four hours per day without feeling guilty of disturbing agriculture officers $(A O)$ outside of the office hours. From past research, there are nine important agriculture information sought by farmers, namely: Information on pest control, Farm safety information, Information on pesticide/weed, Information on paddy varieties, Information on agricultural practices, Crop production information, Information on loan/subsidy, Weather information, and Marketing information.

Based on a survey by MCMC (2018) (Figure 2.0), the most popular communication application is WhatsApp (98.1\%), followed by Facebook Messenger (55.6\%), WeChat (36.8\%), and Telegram (25.0\%). The result showed, the WhatsApp application can help our community to spread and share news extensively.

Figure 2.0: Communication apps account ownership

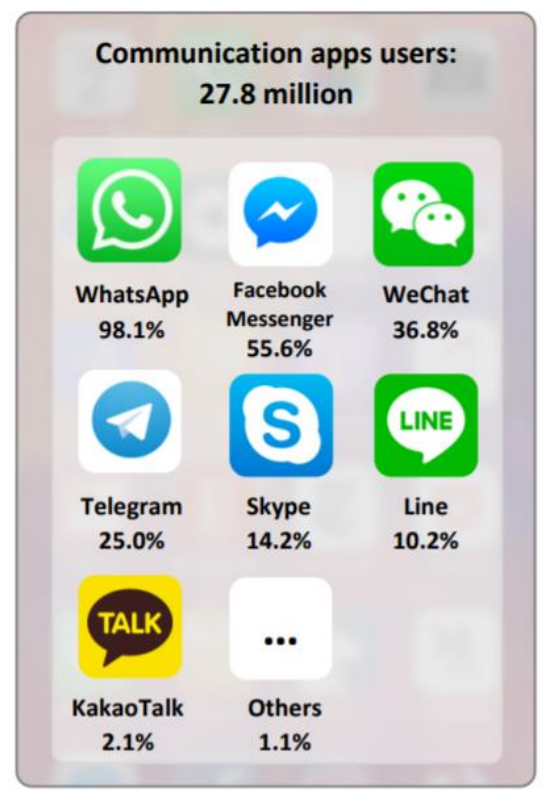

Source: Malaysian Communication and Multimedia Commission (MCMC), 2018

\section{Literature Review}

Nowadays, $95 \%$ of the people worldwide live in an area with mobile network coverage and over $90 \%$ of expected new phone subscriptions in 2020 are situated in the developing countries. Previous studies on the development of mobile phone often presented a debate that ICTs have the potential to aid in rural growth and poverty reduction (Donner, 2008; Duncombe \& Heeks, 2002; Hudson, 2006; Saunders et al., 1994). Furthermore, Richardson et al. (1998) stated that information requirements 
of farmers change from time to time due to the change in agricultural technologies, environmental changes, agricultural policies, and the emergence of agricultural innovations. Likewise, the literature surveyed highlight a fast growth of mobile phones in the emerging developing countries of Asia and their key role in reducing information search costs and increasing market efficiencies.

Moreover, the ability of mobile phones can bring a refreshed momentum to the field of agriculture. According to Yunus (2011), the speediest way to get out of poverty right now is to have one mobile telephone. One example which shows the prosperous usage of ICT in agriculture is "mobile telephony". It has been used to access information on market price, weather, and many other aspects (Pickernell et al., 2004). However, issues such as lack of connectivity and poor quality of services, especially in rural areas, should be addressed by relevant bodies to enable farmers enjoy the perceived benefits of mobile phones. Rural farmers often face a knowledge gap in regard to the best practices in agriculture. Mobile phone services can contribute to bridging the knowledge gap, thus increasing agricultural production and profitability.

\section{Methodology}

The study area chosen for this research is Selangor, Malaysia. Selangor is located in the central region of Peninsular Malaysia which consists of several paddy growing areas. A quantitative study was undertaken to validate the dissemination of information via mobile phone usage with a sample of 400 paddy farmers from Barat Laut Selangor Integrated Agriculture Development Area (IADA) Selangor. To identify the sample, purposive sampling approach was used. Respondents were selected from eight areas (refer Table 1.0) which are: Sawah Sempadan, Sungai Burong, Sekinchan, Sungai Leman, Pasir Panjang, Sungai Nipah, Pancang Bedena, Bagan Terap and Sungai Panjang who currently use mobile phones.

Table 1.0: Sampling technique

\begin{tabular}{|c|c|c|c|c|}
\hline No. & Area & $\begin{array}{c}\text { Number of } \\
\text { farmers (people) }\end{array}$ & $\begin{array}{c}\text { Sampling } \\
(\%)\end{array}$ & Actual Collection \\
\hline 1. & Sawah Sempadan & 1139 & 12.1 & 48 \\
\hline 2. & Sungai Burong & 1651 & 17.5 & 70 \\
\hline 3. & Sekinchan & 784 & 8.3 & 33 \\
\hline 4. & Sungai Leman & 1289 & 13.7 & 55 \\
\hline 5. & Pasir Panjang & 643 & 6.8 & 27 \\
\hline 6. & Sungai Nipah & 987 & 10.4 & 42 \\
\hline 7. & Pancang Bedena & 1684 & 17.8 & 71 \\
\hline 8. & Bagan Terap & 1268 & 13.4 & 54 \\
\hline \multirow[t]{2}{*}{9.} & Sungai Panjang & & & \\
\hline & Total & 9445 & 100 & 400 \\
\hline
\end{tabular}

Sampling $=\frac{x}{\text { Total farmers }} \times 100$

(\%) 
INTERNATIONAL JOURNAL OF ACADEMIC RESEARCH IN BUSINESS AND SOCIAL SCIENCES Vol. 9, No. 6, June, 2019, E-ISSN: 2222-6990 (C) 2019 HRMARS

Based on the calculation, this study selected 400 samples because according to Najib (1999), a bigger sample size will strengthen the reliability and validity of the study.

\section{Results and Discussion}

To analyse the data, SPSS software was used with which analyses such as mean and standard deviation were employed to describe the general data of the study. Table 2.0 shows the importance of agriculture information among paddy farmers. The research instrument examined the frequency of the agriculture information received by sources listed. There were five different degrees of frequency to be chosen by the respondents, where 1=not very important; $2=$ not important; 3=sometimes important; 4=important; and 5=very important.

Table 2.0: Mean and Standard Deviation for items of importance agriculture Information

\begin{tabular}{lcc}
\hline \multicolumn{1}{c}{ Items } & Mean & S.D \\
\hline Information on pest control & 4.53 & .529 \\
Farm safety information & 4.52 & .515 \\
Information on pesticide / weed & 4.50 & .530 \\
Information of paddy varieties & 4.46 & .533 \\
Information on agricultural practices & 4.45 & .555 \\
Crop production information & 4.39 & .659 \\
Information on loan / subsidy & 4.39 & .565 \\
Weather information & 4.02 & .873 \\
Marketing Information & 3.71 & 1.222 \\
\hline \hline
\end{tabular}

The data were analysed using descriptive statistics such as mean and standard deviation (SD). Results reveal that the information on pest control $(M=4.53)$ is the most important information for farmers, followed by farm safety information ( $M=4.52)$. This is because crucial information on pest control will save the paddy crops from catastrophic diseases. This finding is in line with Alibuet et al. (2016) where required information on pest control is ranked first due to production constraint, information about diseases ranked second, and information about weeds ranked third. Furthermore, Babu et al., (2012) found that the important information needs for rice farmers were pest and disease management, pesticide, and fertilizer application. However, this finding contradicts the findings of Diagne et al. (2013) who found weed infestation to be the most important biotic constraint, followed by insect pests, and then birds. This inconsistency may be due to the enormous differences between the 18 major rice-producing countries that were studied by Diagne et al., (2013).

The results also indicate that marketing information is the lowest $(M=3.71)$ because, in Malaysia, the marketing for rice is arranged by Padiberas Nasional Berhad (BERNAS). Bernas is a government organization that aims to facilitate farmers in marketing their yields. Thus, farmers do not need to worry about yield marketing. Besides, information on pest control is a major concern among farmers because pests have the potential to destroy all their crops if they are not careful to handle it. Thus, private companies can always send their messages and promotions to farmers personally to create 
their marketing chain. These findings contradict Benard et al., (2014) who found that the majority of the farmers in their study need information on marketing.

The importance of agricultural information and application using mobile phones is presented in Table 3.0. This item used five different degrees of frequency to be chosen by the respondents, where 1=Never; $2=$ =Slightly Often; 3=Sometimes; 4=Frequent; and 5=Most Often. Additionally, Table 3.0 also discusses the applications used to obtain information, where a=Never used; $b=$ Call; $c=$ Message; $\mathrm{d}=$ WhatsApp; and e=E-Mobile.

Information about pests such as weeds and insects and how to cope (82\%) shows the highest percentage followed by fertilizer or pesticides information (89.8\%). Both the information are essential to every farmer to better prepare and equip themselves with knowledge before any agricultural disaster occurs in their paddy farm. Apart from that, the table also reveals that the WhatsApp application is the most used application by the respondents to get information using a mobile phone. However, mobile phone call is highlighted to get information if they want to know an urgent situation. 
INTERNATIONAL JOURNAL OF ACADEMIC RESEARCH IN BUSINESS AND SOCIAL SCIENCES Vol. 9, No. 6, June, 2019, E-ISSN: 2222-6990 @ 2019 HRMARS

Table 3.0: Frequency for Items of Importance Agriculture Information and Application

\begin{tabular}{|c|c|c|c|c|c|c|c|c|c|c|c|}
\hline \multirow{3}{*}{$\begin{array}{l}\mathbf{N} \\
\mathbf{0} .\end{array}$} & \multicolumn{11}{|l|}{ Usage } \\
\hline & \multirow{2}{*}{$\begin{array}{c}\text { Agricultural } \\
\text { information }\end{array}$} & \multicolumn{5}{|c|}{ Scale (\%) } & \multicolumn{5}{|c|}{ Applications used (\%) } \\
\hline & & 1 & 2 & 3 & 4 & 5 & $\mathbf{a}$ & $\mathbf{b}$ & c & d & e \\
\hline 1. & $\begin{array}{r}\text { Crops information } \\
\text { that have high } \\
\text { potential } \\
\text { (eg: Type of } \\
\text { varieties) }\end{array}$ & $\begin{array}{l}18 \\
.3\end{array}$ & 2.5 & $\begin{array}{c}22 . \\
5\end{array}$ & $\begin{array}{c}55 . \\
8\end{array}$ & 1.0 & 18.3 & $\begin{array}{c}21 . \\
8\end{array}$ & 0.3 & $\begin{array}{c}59 . \\
8\end{array}$ & 0.0 \\
\hline 2. & $\begin{array}{r}\text { Preparatory } \\
\text { agricultural land } \\
\text { information }\end{array}$ & $\begin{array}{l}37 \\
.0\end{array}$ & 8.8 & $\begin{array}{c}16 . \\
8\end{array}$ & $\begin{array}{c}37 . \\
0\end{array}$ & 0.5 & 37.0 & $\begin{array}{c}15 . \\
5\end{array}$ & 0.3 & $\begin{array}{c}47 . \\
3\end{array}$ & 0.0 \\
\hline 3. & $\begin{array}{r}\text { How to care for } \\
\text { plants } \\
\text { (Example: Method } \\
\text { of preparation of } \\
\text { seeds/care tips) }\end{array}$ & $\begin{array}{l}20 \\
.8\end{array}$ & 4.3 & $\begin{array}{c}24 . \\
5\end{array}$ & $\begin{array}{c}49 . \\
3\end{array}$ & 1.3 & 20.8 & $\begin{array}{c}20 . \\
5\end{array}$ & 0.0 & $\begin{array}{c}58 . \\
8\end{array}$ & 0.0 \\
\hline 4. & $\begin{array}{r}\text { Agricultural } \\
\text { equipment } \\
\text { information } \\
\text { (Example: } \\
\text { Machinery) }\end{array}$ & $\begin{array}{c}34 \\
.5\end{array}$ & 6.8 & $\begin{array}{c}23 . \\
5\end{array}$ & $\begin{array}{c}34 . \\
0\end{array}$ & 1.3 & 34.5 & $\begin{array}{c}14 . \\
2\end{array}$ & 0.5 & $\begin{array}{c}50 . \\
7\end{array}$ & 0.0 \\
\hline 5. & $\begin{array}{l}\text { Opportunities for } \\
\text { online marketing }\end{array}$ & $\begin{array}{l}30 \\
.8\end{array}$ & 0.8 & 6.8 & $\begin{array}{c}58 . \\
8\end{array}$ & 3.0 & 3.0 & $\begin{array}{c}30 . \\
8\end{array}$ & 0.3 & $\begin{array}{c}65 . \\
8\end{array}$ & 0.3 \\
\hline 6. & Price of crops & $\begin{array}{l}31 \\
.8\end{array}$ & 2.0 & 4.0 & $\begin{array}{c}61 . \\
8\end{array}$ & 0.5 & 0.5 & $\begin{array}{c}30 . \\
5\end{array}$ & 0.5 & $\begin{array}{c}68 . \\
3\end{array}$ & 0.3 \\
\hline 7. & $\begin{array}{l}\text { Harvesting } \\
\text { techniques }\end{array}$ & $\begin{array}{l}10 \\
.3\end{array}$ & 4.3 & $\begin{array}{c}63 . \\
5\end{array}$ & $\begin{array}{c}19 . \\
5\end{array}$ & 2.5 & 26.8 & 9.3 & 0.3 & $\begin{array}{c}63 . \\
5\end{array}$ & 0.3 \\
\hline 8. & $\begin{array}{r}\text { Fertilizers / } \\
\text { pesticides } \\
\text { information }\end{array}$ & $\begin{array}{l}2 . \\
0\end{array}$ & 1.0 & 6.5 & $\begin{array}{c}89 . \\
8\end{array}$ & 0.8 & 0.0 & 0.8 & 10.0 & $\begin{array}{c}89 . \\
3\end{array}$ & 0.0 \\
\hline 9. & $\begin{array}{r}\text { Information about } \\
\text { pests and how to } \\
\text { cope } \\
\text { (Example: Weeds, } \\
\text { insects) }\end{array}$ & $\begin{array}{l}5 . \\
3\end{array}$ & 3.8 & 8.8 & $\begin{array}{c}82 . \\
0\end{array}$ & 0.3 & 0.5 & 1.3 & 16.5 & $\begin{array}{c}81 . \\
8\end{array}$ & 0.0 \\
\hline 10 & $\begin{array}{l}\text { Financial / capital } \\
\text { / loan information }\end{array}$ & $\begin{array}{l}11 \\
.3\end{array}$ & 4.0 & $\begin{array}{c}56 . \\
5\end{array}$ & $\begin{array}{c}26 . \\
8\end{array}$ & 1.5 & 35.5 & 7.2 & 0.8 & $\begin{array}{c}56 . \\
3\end{array}$ & 0.3 \\
\hline $\begin{array}{r}11 \\
.\end{array}$ & $\begin{array}{r}\text { Weather } \\
\text { information }\end{array}$ & $\begin{array}{l}10 \\
.8 \\
\end{array}$ & 3.8 & $\begin{array}{c}72 . \\
8 \\
\end{array}$ & $\begin{array}{c}12 . \\
0\end{array}$ & 0.8 & 22.8 & 4.0 & 0.3 & $\begin{array}{c}72 . \\
8 \\
\end{array}$ & 0.3 \\
\hline
\end{tabular}

1= Never; 2=Slightly Often; 3=Slightly Sometimes; 4= Frequent; 5= Most Often 
$a=$ Never used; $b=$ Call; $c=$ Message $(S M S) ; d=$ WhatsApp; $e=$ E-mobile

Based on the results in Table 3.0, paddy farmers are more inclined to using mobile phones than contacting the agricultural officers or extension agents in order to get information about agriculture. These findings show differences with past researchers such as Hassan et al. (2010); Odiaka and Obinna (2010); Shaffril et al. (2009); and Umeh (2008). The past researchers stressed that the rural community prefer to obtain information about agriculture through different media such as television and newspaper.

The main challenge among older farmers in using a mobile phone is that the keypad is too small which can make it difficult for them to identify the alphabets. Furthermore, their fingers are big and rough, making it harder for them to use the keypad which is suitable for the younger generation. Albeit, a few successful farmers use Android mobile phones that are equipped with big screen. But, for some older farmers, they like to use classic mobile phones because the screen of an Android mobile phone is more sensitive which becomes a challenge for them to use the mobile phone. Another problem in using mobile phones among farmers is that it requires a high cost for continuous usage. Based on their income, it may become a burden for them to continuously use mobile phones actively due to the telco-charge. The results shown in Table 4.0 prove that problems subsisted are caused by cost $(\mathrm{M}=3.40)$. 
INTERNATIONAL JOURNAL OF ACADEMIC RESEARCH IN BUSINESS AND SOCIAL SCIENCES Vol. 9, No. 6, June, 2019, E-ISSN: 2222-6990 @ 2019 HRMARS

Table 4.0: Mean and Standard Deviation for items problems of mobile phone usage

\begin{tabular}{|c|c|c|c|c|c|c|c|}
\hline \multirow[t]{2}{*}{ Items } & \multicolumn{5}{|c|}{$\begin{array}{l}\text { Likert Scale } \\
\text { (\% of frequency) }\end{array}$} & \multirow[t]{2}{*}{ Mean } & \multirow[t]{2}{*}{ SD } \\
\hline & 1 & 2 & 3 & 4 & 5 & & \\
\hline $\begin{array}{l}\text { It is difficult to send a message (keypad too } \\
\text { small) }\end{array}$ & 14.8 & 10.3 & 13.3 & 20.5 & 41.3 & 3.63 & $\begin{array}{r}1.46 \\
7\end{array}$ \\
\hline It is easily broken/damaged & 12.3 & 14.0 & 13.5 & 25.5 & 34.8 & 3.57 & $\begin{array}{r}1.40 \\
0\end{array}$ \\
\hline Screen size is too small & 14.0 & 12.8 & 16.0 & 17.3 & 40.0 & 3.56 & $\begin{array}{r}1.46 \\
5\end{array}$ \\
\hline The battery life is too short & 14.2 & 12.0 & 18.3 & 17.8 & 37.8 & 3.53 & $\begin{array}{r}1.45 \\
1\end{array}$ \\
\hline Access to the internet is slow & 20.3 & 7.5 & 10.5 & 26.8 & 35.0 & 3.49 & $\begin{array}{r}1.52 \\
3\end{array}$ \\
\hline Phone signal is weak and inconsistent & 13.0 & 8.8 & 22.5 & 32.3 & 23.5 & 3.45 & $\begin{array}{r}1.29 \\
5\end{array}$ \\
\hline It requires a high cost for continuous usage & 9.8 & 13.0 & 20.3 & 41.5 & 15.5 & 3.40 & $\begin{array}{r}1.18 \\
3\end{array}$ \\
\hline $\begin{array}{l}\text { It does not have the characteristics to access } \\
\text { the internet (Prepaid users) }\end{array}$ & 28.0 & 13.0 & 4.0 & 21.5 & 33.5 & 3.20 & $\begin{array}{r}1.66 \\
6\end{array}$ \\
\hline The memory space is too limited & 17.3 & 18.3 & 19.8 & 27.0 & 17.8 & 3.10 & $\begin{array}{r}1.35 \\
9\end{array}$ \\
\hline It is not user-friendly & 19.0 & 18.3 & 10.5 & 40.5 & 11.8 & 3.08 & $\begin{array}{r}1.34 \\
8\end{array}$ \\
\hline Rapidly changing phone model & 21.5 & 15.8 & 11.3 & 38.8 & 12.8 & 3.05 & $\begin{array}{r}1.38 \\
4\end{array}$ \\
\hline $\begin{array}{l}\text { It is difficult to use the features on your } \\
\text { mobile phone }\end{array}$ & 16.8 & 29.8 & 15.5 & 31.8 & 6.3 & 2.81 & $\begin{array}{r}1.22 \\
6\end{array}$ \\
\hline Too much time spent on call so addictive & 73.0 & 16.5 & 3.8 & 3.8 & 3.0 & 1.47 & .955 \\
\hline
\end{tabular}

Thus, to overcome these problems, farmers nowadays are using an application known as 'WhatsApp' that can be installed through the application store in the mobile phones that have access to the Internet. Through this app, the farmers can create groups among them including Agriculture Officer (AO) as their knowledge expert. For example, IADA paddy farmers have their own WhatsApp group. Through this group, they can ask, share, debate, and learn about paddy farming. For any technical discussion, the AO will guide and give explanation to the farmers in this group.

\section{Conclusion and Recommendation}

As a conclusion, mobile phones are the best choice for paddy farmers in seeking agricultural information. Thus, this is the suitable time for our government to take action and follow our neighbouring countries to develop mobile apps intended for the use of paddy farmers. For example, the Philippines has developed NMRice Mobile app and Myanmar has Green Way mobile app. 
Applications such as these will help our farmers to get information through a mobile phone with increased efficiency. Furthermore, the extension agent needs to conduct adequate workshops, training, and awareness in order to educate the farmers on how to learn and use mobile phone technology. Babu et al., (2012) stated that a better understanding of farmers' agricultural information needs and information sources could help guide the extension and other agricultural programs to better target specific groups of farmers.

Moreover, the study emphasizes the vital importance of complementary skills and other organizations to realize the full potential of better access to telecommunications. There is no advantage in access to better information if it cannot be leveraged (Mittal et al., 2010).

Thus, mobile phones are worthwhile for farmers to save their time, decrease price disparity, and reduction in transportation and information costs. The results of this research show that mobile phones have tremendous potential to help our farmers to become E-farmers when they know how to search for information using a mobile phone. Knowledge will empower the farming communities to improve their livelihoods and build a more sustainable and resilient agriculture.

\section{Contribution}

This study has highlighted several novel contributions. The first contribution of this study is proved by several studies such as Hellstrom (2010), Souter et al. (2005), and Sife et al. (2010). They agreed that mobile phones can contribute to the development of agriculture and rural areas. Mobile phones can enhance the opportunities for increased income for farmers and are a tool for reducing vulnerabilities for smallholder crop farmers in rural areas of the least developed countries. The second contribution of this study is verified by studies such as Katengeza, et al. (2011) and Lwasa et al. (2011). The two empirical studies based on mobile phone users have proved that a greater distance of farmers from markets (i.e., greater remoteness) implied a greater intensity of phone use. The advent of mobile phones is stimulating a revolution in rural connectivity for smallholder farmers and other small-scale rural producers in developing countries.

\section{References}

Alibu, S., Otim, M.H., Okello, S.E.A., Lamo, J., Moses Ekobu, M., Asea, G. (2016). Farmer's Knowledge and Perceptions on Rice Insect Pests and Their Management in Uganda. Academic Editor: Les Copeland. Received: 21 March 2016; Accepted: 30 May 2016; Published: 17 August 2016. Available at (http://creativecommons.org/licenses/by/4.0/).

Babu, S. C., Glendennin, C. J, Asenso, O. K, Govindarajan, S. K. (2012). Farmers' Information Needs and Search Behaviour: Case Study in Tamil Nadu, India. IFPRI discussion paper 01165. The International Food Policy Research Institute. 1-37.

Diagne, A., Alia, D. Y., Amovin, A. E., Wopereis, M. C. S., Saito, K., Nakelse, T. (2013). Farmer perceptions of the biophysical constraints to rice production in sub-Saharan Africa, and potential impact of research. In Realizing Africa's Rice Promise, Wopereis, M.C.S., Johnson, D.E., Ahmadi, N., Tollens, E., Jalloh, A., Eds. CABI: Accra, Ghana, pp. 46-68. 
INTERNATIONAL JOURNAL OF ACADEMIC RESEARCH IN BUSINESS AND SOCIAL SCIENCES

Vol. 9, No. 6, June, 2019, E-ISSN: 2222-6990 @ 2019 HRMARS

Donner, J. (2008). Research approaches mobile use in the developing world: A review of the literature. The Information Society, 24(3), 140-159.

Hassan, M. S. Shaffril, H. A. M. Ali, M. S. S. and Ramli, N. S. (2010). Agriculture agency, mass media and farmers: A combination for creating knowledgeable agriculture community. African J. Agric. Res., 5: 3500-3513.

Hellstrom, J. (2010). The Innovative Use of Mobile Applications in East Africa. Swedish International Development Cooperation Agency Review 2010:12, SIDA, Stockholm, Sweden.

URL http://www.sida.se/publications.

Hosseini, S. J. F., Niknami, M. and Chizari, M. (2009). To determine the challenges in the application of ICTs by the agricultural extension service in Iran. Journal of Agricultural Extension and Rural Development, 1(1): 27-30.

Katengeza, S. P., Okello, J. J. \& Jambo, N. (2011). Use of mobile phone technology in agricultural marketing: the case of small holder farmers in Malawi, International Journal of ICT Research and Development in Africa, 2 (2):14-25. [21].

Lwasa, S., Asingwire, N., Okello, J.J. \& Kiwanuka, J. (2011). Awareness of ICT-based projects and intensity of use of mobile phones among small holder farmers in Uganda: the case of Mayuge and Apac districts, International Journal of ICT Research and Development in Africa, 2 (2): 2638. [25]

Mittal, S., Gandhi, S. Tripathi, G. (2010). Socio-Economic Impact of Mobile Phones on Indian Agriculture. Indian Council for Research on International Economic Relations. Working Paper No. 246.

Oladele, O. (2006). Multilinguality of farm broadcast and agricultural information accessing Nigeria. Nordic J. Afr. Studies, 15(2): 199-205.

Available at http://www.njas.helsinki.fi/pdf-files/vol15num2/oladele5.pdf

Odiaka, E. C and Obinne, C. P. (2010). Co-orientation in gender preferences for mass media usage among Benue farmers. J. Agric. Food Information, 11: 322-329

DOI:10.1080/10496505.2010.512249

Shaffril, H. A. M., Hassan, M. S. and Beydha, I. (2009). Level of Mass Media Usage (Television, Radio and Newspaper) among Malaysian Agro-Based Entrepreneurs. J. Commun. Knowl. Commun., 1:28-38.

Sife, A. S., Kiondo, E. and Lyimo-Macha, J. G. (2010). Contribution of Mobile Phones to Rural Livelihoods and Poverty Reduction in Morogoro Region, Tanzania, The Electronic Journal of Information Systems in Developing Countries, 42, 3, 1-15.

Souter, D., Scott, N., Garforth, C., Jain, R., Mascarenhas, O. and McKemey, K. (2005). The Economic Impact of Telecommunications on Rural Livelihoods and Poverty Reduction: A study of rural communities in India (Gujarat), Mozambique and Tanzania. Landon: Commonwealth Telecommunications Organisation UK Department for International Development.

http://www.telafrica.org/R8347/files/pdfs/FinalReport.pdf

Umeh, G. N. (2008). Assessment of Mass Media Usage for Farm Information By Farmers In Afikpo LGA of Ebonyi State: Implication for Information and Communication Technology (ICT) Application to Agricultural Technology Transfer.Continental Journal Information Technology, 2:9-12.

Yunus, M. (2009). Mobile telephony in rural areas. E-Agriculture, Policy Brief - March 2009. 